\title{
Mixed bivalent transition metal complexes of 1,10-phenanthroline and 2-aminomethylthiophenyl-4-bromosalicylaldehyde Schiff base: Spectroscopic, molecular modeling and biological activities
}

\author{
Mutlaq Shedeed Aljahdali a, Ahmed Abdou El-Sherif b,c,*, \\ Rifaat Hasan Hilal a,b and Abeer Taha Abdel-Karim ${ }^{b}$ \\ a Department of Chemistry, Faculty of Science, King Abdulaziz University, Jeddah 21589, Kingdom of Saudi Arabia \\ b Department of Chemistry, Faculty of Science, Cairo University, Giza, 12613, Egypt \\ c Department of Chemistry, Faculty of Arts and Science, Northern Borders University, Rafha-156, Kingdom of Saudi Arabia \\ ${ }^{*}$ Corresponding author at: Department of Chemistry, Faculty of Science, Cairo University, Giza, 12613, Egypt. \\ Tel.: +2.0106.0160168; fax: +2.02.5676562. E-mail address: aelsherif72@yahoo.com (A.A. El-Sherif).
}

\section{ARTICLE INFORMATION}

Received: 21 April 2013

Received in revised form: 26 June 2013

Accepted: 26 June 2013

Online: 31 December 2013

\section{KEYWORDS}

Schiff base

Bivalent metals

Biological activity

Antitumor activity

Electronic spectra

Mixed-ligand complexes

\begin{abstract}
Mixed ligand complexes of $\mathrm{M}(\mathrm{II})\{\mathrm{M}=\mathrm{Cu}(\mathrm{II}), \mathrm{Ni}(\mathrm{II}), \mathrm{Co}(\mathrm{II})$ and $\mathrm{Zn}(\mathrm{II})\}$ with 1,10 phenanthroline (1,10-Phen) and Schiff base namely 2-aminomethylthiophenyl-4bromosalicylaldehyde (ATS) have been synthesized. These metal chelates have been characterized by elemental analyses, IR, ${ }^{1} \mathrm{H}$ NMR, solid reflectance, magnetic moment and molar conductance. Spectral data showed that the 1,10-phenanthroline act as neutral bidentate ligand coordinating to the metal ion through two nitrogen donor atoms and Schiff base (ATS) acts as monobasic bidentate coordinating through through azomethine- $N$ and phenolic-oxygen groups. The geometry of the studied M(II) complexes has been fully optimized. The metal chelates have been screened for their antimicrobial activities using the disc diffusion method against different selected types of bacteria and fungi. In vitro antitumor activity assayed against two human cell lines colon (HCT116) and larynx (HEP2) cancer cells. Solution equilibrium studies were also investigated.
\end{abstract}

\section{Introduction}

One of the major applications of the transition metal complexes is their evaluation as antibacterial and antitumor agents aiming toward the discovery of effective and safe therapeutic agents for the treatment of bacterial infections and cancers. In addition, many Schiff base complexes with metals have a diverse spectrum of biological and pharmaceutical activities, including antitumor [1,2], antifungal [3,4], antioxidative [5,6] and antibacterial activities [7-9]. Schiff bases and their complexes have been used as biological models to understand the structure of biomolecules and biological processes [10]. The study of ternary complexes involving an aromatic Schiff base and 1,10-phenanthroline has been studied extensively [11]. It is well known that some drugs exhibit increased activity when administered as metal complexes [1214] and several metal chelates have been shown to inhibit tumor growth [15]. Some research groups found that the Schiff base metal complexes derived from salicylaldehyde can specially cleave the DNA $[16,17]$. As it is known to all, thiophene derivatives have intensively antibacterial and antitumor activities [18-20]. Also, metal complexes of Schiff bases with heterocyclic compounds find applications as potential drugs [7,8,21]. 1,10-Phenanthroline (Figure 1) is the parent of an important class of chelating agents. Considerable attention has been paid in recent years to the investigation of the complex-forming properties of 1,10-phenanthroline because of its outstanding biological significance [22,23]. Previously, we have reported our interesting results on the synthesis, equilibrium studies and antimicrobial activities of binary complexes of 2-aminomethylthiophenyl-4-bromosalicylaldehyde (ATS) (Figure 1) [20]. Encouraged by this result and in continuation of our published work in the coordination chemistry of bioactive ligands [24-30], we turned our attention towards the synthesis, spectral characterization and biological studies of ternary complexes involving some transition metal ions, 1,10-Phenanthroline (1,10-phen) and ATS specially a thorough literature survey reveals that no work has been done on the synthesis and biological studies of ternary complexes of Schiff base containing thiophene moiety and phenanthroline.

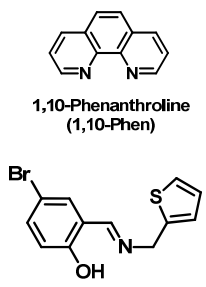

2-Aminomethylthiophenyl-4-bromosalicylaldehyde Schiff base (ATS)

Figure 1. Structural formula of ATS-Schiff base and 1,10-phen.

\section{Experimental}

\subsection{Materials}

All chemicals used were of analytical reagent grade (AR), and of the highest purity available. They included $\mathrm{CuCl}_{2} .2 \mathrm{H}_{2} \mathrm{O}$ 
(Sigma), $\mathrm{CoCl}_{2} .6 \mathrm{H}_{2} \mathrm{O}$ and $\mathrm{NiCl}_{2} .6 \mathrm{H}_{2} \mathrm{O}(\mathrm{BDH}), \mathrm{ZnCl}_{2} .2 \mathrm{H}_{2} \mathrm{O}, \mathrm{C}_{2} \mathrm{H}_{5} \mathrm{OH}$ (Sigma), DMSO (BDH), 5-bromosalicylaldehyde (Aldrich); 1,10phenanthroline (Sigma) and 2-aminomethylthiophene (Aldrich).

\subsection{Preparation of Schiff base}

The ATS Schiff base was prepared as reported in literature [20] by mixing an ethanolic solution $(20 \mathrm{~mL})$ of $2.01 \mathrm{~g}(0.01$ $\mathrm{mol})$ of 5-bromosalicylaldehyde with $1.13 \mathrm{~g}(0.01 \mathrm{~mol})$ of 2aminomethylthiophene in the same volume of ethanol. The mixture then refluxed with stirring for 1 hour. The precipitate was collected by filtration through Buchner funnel, recrystallized from ethanol and dried at room temperature with $89 \%$ yield.

\subsection{Preparation of mixed-ligand complexes}

1,10-Phenanthroline and the transition metal chlorides were used as purchased without any further purification. The mixed ligand complexes under investigation were prepared by mixing the appropriate molar quantity of ligands and metal chloride using the following procedure. An ethanolic solution mixture of Schiff base (ATS) (20 mL; 0.1mole) and 1,10-phen (20 mL; 0.1 mole) was refluxed with the aqueous-ethanolic solution of metal salt ( $20 \mathrm{~mL} ; 0.1 \mathrm{~mole}$ ) for $4-5 \mathrm{~h}$. The colored solid product formed was filtered, washed with ethanol, and dried in a desiccator over anhydrous calcium chloride under vacuum. The yield ranged from $71-77 \%$. The dried complexes were subjected to elemental and spectroscopic analysis.

\subsection{Molecular modeling}

All quantum mechanics computations have been performed using the Gaussian 09W program package [31]. Optimization of the structures of the ligands and of the metal (II) complexes was carried out at the DFT/ B3LYP [32-34] level of theory using the Lanl2dz basis set $[35,36]$. All geometric parameters were allowed to relax and the global minimum structure has been identified by calculating the matrix of second derivative and ensures that all its Eigen values are positive. Natural bond order analysis has been carried out using NBO 3.0 program $[37,38]$ as implemented in the G09W package.

\subsection{Pharmacology}

\subsubsection{In vitro antibacterial and antifungal activities}

The synthesized complexes were screened in vitro for their biological activity by using four bacteria, namely Shigella flexneri, Proteous vulgaris as Gram -ve, Staphylococcus aureus and Bacillus subtillis as Gram +ve and two fungi, namely Aspergillus fumigatus and Candida albicans. These bacterial strains were chosen as they are known human pathogens. Antimicrobial activity of the tested samples was determined using a modified Kirby-Bauer disc diffusion method [39]. The stock solution $(1 \mathrm{mg} / \mathrm{mL})$ of the test chemical compound was prepared by dissolving $20 \mathrm{mg}$ of the test compound in $20 \mathrm{~mL}$ of dimethyl sulfoxide (DMSO) solvent. Briefly, $100 \mu \mathrm{L}$ of the test bacteria/fungi were grown in $10 \mathrm{~mL}$ of fresh media until they reached a count of approximately 108 cells $/ \mathrm{mL}$ or 105 cells $/ \mathrm{mL}$ for fungi [40]. $100 \mu \mathrm{L}$ of microbial suspension was spread onto agar plates corresponding to the broth in which they were maintained. Isolated colonies of each organism that might be playing a pathogenic role should be selected from primary agar plates and tested for susceptibility by disc diffusion method of the National Committee for Clinical Laboratory Standards (NCCLS) [41]. Of the many media available, NCCLS recommends Müeller-Hinton agar due to it results in good batch-to-batch reproducibility. The petri dishes were incubated at $30{ }^{\circ} \mathrm{C}$ for fungi and at $35-37{ }^{\circ} \mathrm{C}$ for bacteria. The diameter of the zone of inhibition was measured in millimeters after $24 \mathrm{~h}$ of incubation
[42]. Standard discs of Gentamicin and Ampicillin (antibacterial agents), Amphotericin B (antifungal agent) served as positive controls for antimicrobial activity but filter discs impregnated with $10 \mu \mathrm{L}$ of solvent (DMSO) were used as a negative control. The agar used is Meüller-Hinton agar that is rigorously tested for composition and $\mathrm{pH}$. Further the depth of the agar in the plate is a factor to be considered in the disc diffusion method. This method is well documented and standard zones of inhibition have been determined for susceptible and resistant values. Blank paper disks (Schleicher and Schuell, Spain) with a diameter of $8.0 \mathrm{~mm}$ were impregnated with $10 \mu \mathrm{L}$ of tested concentration of the stock solutions. When a filter paper disc impregnated with a tested chemical is placed on agar, the chemical will diffuse from the disc into the agar. This diffusion will place the chemical in the agar only around the disc. The solubility of the chemical and its molecular size will determine the size of the area of chemical infiltration around the disc. If an organism is placed on the agar, it will not grow in the area around the disc if it is susceptible to the chemical. This area of no growth around the disc is known as a "Zone of inhibition" or "Clear Zone". For the disc diffusion, the zone diameters were measured with slipping calipers of the NCCLS [43]. Agar-based methods such as E-test and disk diffusion can be good alternatives because they are simpler and faster the brothbased methods [44].

\subsubsection{Minimum inhibitory concentration (MIC)}

Compounds showing promising antibacterial activity were selected for minimum inhibitory concentration (MIC) studies. The MIC is the lowest concentration of the test compound, which inhibits the visible growth of microorganisms after incubation, and the minimum inhibitory concentration $s$ are important in diagnostic laboratories to confirm the resistance of microorganisms to antimicrobial agents. The synthesized compounds were screened against bacterial strains using agar plate method, two fold serial dilutions of each test compound were used. The culture of each organism was diluted by sterile distilled water to $10^{5}-10^{6} \mathrm{CFU} / \mathrm{mL}$. The cultures were incubated with bacteria at $37{ }^{\circ} \mathrm{C}$ for $24 \mathrm{~h}$. DMSO was used as negative control.

\subsubsection{In-vitro cytotoxicity}

The synthesized complexes were screened for their cytotoxicity against colon carcinoma (HCT116) and larynx carcinoma (HEP2) cells by using the protocol of SRB assay [45] Cells were plated in 96-multiwell plate $\left(10^{4}\right.$ cells/well) for $24 \mathrm{~h}$ before treatment with the compounds to allow attachment of cells to the wall of plate. Different concentrations of the test chemical compound were added to the cell monolayer Triplicate wells were prepared for each individual dose and $\mathrm{IC}_{50}$ is the mean of three values. Monolayer cells were incubated for $48 \mathrm{~h}$ at $37{ }^{\circ} \mathrm{C}$ in air with $5 \% \mathrm{CO}_{2}$. After $48 \mathrm{~h}$, cells were fixed, washed and stained with Sulfo-Rhodamine-B stain Excess stain was washed with acetic acid and attached stain was recovered with tris-EDTA buffer. Color intensity is measured in an ELISA reader. The average drug concentration $\left(\mu \mathrm{g} / \mathrm{cm}^{3}\right)$ for $50 \%$ inhibition of tumor cell-growth was determined by plotting the surviving fraction versus drug concentration for each tumor cell line.

\subsection{Instrumentation}

Potentiometric measurements were made using a Metrohm 686 titroprocessor equipped with a 665 Dosimat (SwitzerlandHerisau). A thermostatted glass-cell was used equipped with a magnetic stirring system, a Metrohm glass electrode, a thermometric probe, a microburet delivery tube and a salt bridge connected with the reference cell filled with $0.1 \mathrm{M} \mathrm{KCl}$ solution in which saturated calomel electrode was dipped. 
Table 1. Analytical and physical data of compounds.

\begin{tabular}{|c|c|c|c|c|c|c|}
\hline \multirow[t]{2}{*}{ Compound * } & \multirow[t]{2}{*}{ Yield, \% } & \multirow[t]{2}{*}{ M.wt., g } & \multicolumn{4}{|c|}{ \% Found (Calcd.) } \\
\hline & & & C & $\mathrm{H}$ & $\mathbf{N}$ & $\mathbf{S}$ \\
\hline ATS & 89 & 295.9 & $48.49(48.66)$ & $3.39(3.37)$ & $4.80(4.73)$ & $10.89(10.81)$ \\
\hline$\left[\mathrm{Cu}(1,10\right.$-phen $\left.)(\mathrm{ATS})\left(\mathrm{H}_{2} \mathrm{O}\right)_{2}\right] \mathrm{Cl}$ & 77 & 609.94 & $47.46(47.21)$ & $3.49(3.44)$ & $6.88(6.88)$ & $5.39(5.24)$ \\
\hline$\left[\mathrm{Ni}(1,10\right.$-phen $\left.)(\mathrm{ATS})\left(\mathrm{H}_{2} \mathrm{O}\right)_{2}\right] \mathrm{Cl}$ & 75 & 605.09 & $47.46(47.59)$ & 3.49 (3.47) & $6.88(6.94)$ & $5.39(5.28)$ \\
\hline$\left[\mathrm{Co}(1,10\right.$-phen $\left.)(\mathrm{ATS})\left(\mathrm{H}_{2} \mathrm{O}\right)_{2}\right] \mathrm{Cl}$ & 71 & 605.33 & $47.46(47.57)$ & $3.49(3.46)$ & $6.88(6.93)$ & $5.39(5.28)$ \\
\hline$[\mathrm{Zn}(1,10$-phen)(ATS)]Cl & 73 & 575.79 & $50.11(50.02)$ & $3.02(2.95)$ & $7.35(7.29)$ & $5.62(5.55)$ \\
\hline
\end{tabular}

*ATS = 2-Aminomethylthiophenyl-4-bromosalicylaldehyde and 1,10-phen = 1,10-phenanthroline.

Table 2. Tentative assignment of the important infrared bands of the synthesized complexes.

\begin{tabular}{|c|c|c|c|c|c|c|c|c|}
\hline \multirow[t]{2}{*}{ Complex * } & \multicolumn{8}{|l|}{$v\left(\mathrm{~cm}^{-1}\right)$} \\
\hline & $v_{\mathrm{OH}}$ & $v_{C=N}$ & $\delta_{(0-H)}$ & $v_{(C-0)}$ & Coordinated $\mathrm{H}_{2} \mathrm{O}$ & $v_{(C-S-C)}$ & $v_{M-0}$ & $v_{M-N}$ \\
\hline ATS/1,10-phen & 3361 & 1675,1570 & 1361 & 1319 & - & 825 & - & - \\
\hline$\left[\mathrm{Cu}(1,10\right.$-phen $\left.)(\mathrm{ATS})\left(\mathrm{H}_{2} \mathrm{O}\right)_{2}\right] \mathrm{Cl}$ & 3465-3595 & 1657,1542 & 1461 & 1340 & 779 & 824 & 540 & 398 \\
\hline$\left[\mathrm{Ni}(1,10\right.$-phen $\left.)(\mathrm{ATS})\left(\mathrm{H}_{2} \mathrm{O}\right)_{2}\right] \mathrm{Cl}$ & $3440-3577$ & 1655,1543 & 1463 & 1338 & 782 & 825 & 525 & 391 \\
\hline$\left[\mathrm{Co}(1,10\right.$-phen $\left.)(\mathrm{ATS})\left(\mathrm{H}_{2} \mathrm{O}\right)_{2}\right] \mathrm{Cl}$ & $3390-3560$ & 1653,1543 & 1460 & 1342 & 770 & 823 & 512 & 385 \\
\hline$[\mathrm{Zn}(1,10$-phen $)(\mathrm{ATS})] \mathrm{Cl}$ & - & 1653,1545 & 1459 & 1346 & - & 826 & 505 & 375 \\
\hline
\end{tabular}

*ATS = 2-Aminomethylthiophenyl-4-bromosalicylaldehyde and 1,10-phen = 1,10-phenanthroline.

Temperature was maintained constant inside the cell at $25.0 \pm 0.02{ }^{\circ} \mathrm{C}$, by the circulating water by a thermostated bath (Precision \pm 0.02 ). All potentiometric measurements in this study were carried out in water-DMSO mixtures containing $70 \%$ DMSO because of low solubility of Schiff base ligand and possible hydrolysis in aqueous solution. Elemental analyses were carried out at the Department of Chemistry, Faculty of Science, King Abdul-Aziz University, Jeddah21589, KSA. The analyses were performed twice to check the accuracy of the analyses data. Infrared spectra were recorded on an 8001-PC FTIR Shimadzu spectrophotometer using $\mathrm{KBr}$ pellets. The solid reflectance spectra were measured on a Schimadzu 3101 pc spectrophotometer. The molar conductance of the complexes was measured for $1.00 \times 10^{-3} \mathrm{M}$ DMSO solutions at $25 \pm 1{ }^{\circ} \mathrm{C}$ using a systronic conductivity bridge type 305 . The room temperature magnetic susceptibility measurements for the complexes were determined by the Gouy balance using $\mathrm{Hg}\left[\mathrm{Co}(\mathrm{SCN})_{4}\right]$ as a calibrant. The ${ }^{1} \mathrm{H}$ NMR spectra were recorded using a Bruker ARX-300 instrument. Chemical shifts are reported in parts per million ( $\mathrm{ppm})$ relative to tetramethylsilane using deuterated DMSO as solvent.

\subsection{Potentiometric titrations}

The potentiometric cell was calibrated before each experiment to convert the $\mathrm{pH}$ meter readings into hydrogen ion concentration as reported in literature [46]. The ionic product $\left(\mathrm{K}_{\mathrm{w}}=\left[\mathrm{H}^{+}\right]\left[\mathrm{OH}^{-}\right]\right)$was calculated at a constant ionic strength of $0.10 \mathrm{~mol} / \mathrm{dm}^{3}$ with $\mathrm{NaCl}$ in $70 \%$ aqueous DMSO solutions based on measurements of $\left[\mathrm{OH}^{-}\right]$and $\mathrm{pH}$ in several series of experiments. We calaculated the reproducible values of $\mathrm{pK}_{\mathrm{w}}$ for the examined $70 \%$ aqueous dimethyl sulfoxide solution [47]. The $\mathrm{pK}_{w}$ value obtained is $15.75( \pm 0.2)$ in this medium.

Potentiometric titrations were carried out at constant temperature and in an inert atmosphere of nitrogen with $\mathrm{CO}_{2}-$ free standardized $0.05 \mathrm{~mol} / \mathrm{dm}^{3} \mathrm{NaOH}$ as titrant in a $40.0 \mathrm{~mL}$ solution at constant ionic strength of $0.1 \mathrm{~mol} / \mathrm{dm}^{3} \mathrm{NaCl}$. The proton association constants of the ATS ligand was determined potentiometrically by titrating $\left(1.25 \times 10^{-3} \mathrm{M}\right)$ of the ligand solution $\left(40 \mathrm{~cm}^{3}\right)$. The stability constants of the binary complexes were determined using potentiometric data obtained from $\left(40 \mathrm{~cm}^{3}\right)$ mixture containing $\mathrm{CuCl}_{2} 2 \mathrm{H}_{2} \mathrm{O} /$ $\mathrm{CoCl}_{2} \cdot 6 \mathrm{H}_{2} \mathrm{O} / \mathrm{NiCl}_{2} \cdot 6 \mathrm{H}_{2} \mathrm{O} / \mathrm{ZnCl}_{2} \cdot 2 \mathrm{H}_{2} \mathrm{O}\left(1.25 \times 10^{-3} \mathrm{M}\right)+(\mathrm{ATS})$ $\left(2.5 \times 10^{-3} \mathrm{M}\right)$.

The potentiometric cell was calibrated before each experiment so as to measure the hydrogen ion concentration rather than its activity. The $\mathrm{pH}$-meter readings (B) recorded in DMSO-water solutions were converted to hydrogen ion concentration $\left[\mathrm{H}^{+}\right]$by using the widely used relation given by Van Uitert and Hass Equation (1) [48] as shown below. $-\log \left[\mathrm{H}^{+}\right]=B+\log U_{\mathrm{H}}$

where $\log U_{H}$ is the correction factor for the solvent composition and ionic strength for which $B$ is read.

The equilibrium constants evaluated from the titration data are defined by Equations (2) and (3), where $\mathrm{M}, \mathrm{L}$ and $\mathrm{H}$ stand for the metal(II) ion $\left(\mathrm{Cu}^{2+}, \mathrm{Zn}^{2+}, \mathrm{Co}^{2+}\right.$ and $\left.\mathrm{Ni}^{2+}\right)$, Schiff base ligand (ATS) and proton, respectively.

$\mathrm{pM}+\mathrm{qL}+\mathrm{rH} \rightleftharpoons \mathrm{M}_{\mathrm{p}} \mathrm{L}_{\mathrm{q}} \mathrm{H}_{\mathrm{r}}$

$\beta_{\mathrm{pqr}}=\frac{\left[\mathrm{M}_{\mathrm{p}} \mathrm{L}_{\mathrm{q}} \mathrm{H}_{\mathrm{r}}\right]}{[\mathrm{M}]^{\mathrm{p}}[\mathrm{L}]^{\mathrm{q}}[\mathrm{H}]^{\mathrm{r}}}$

The calculations were obtained from ca. 100 data points in each titration using the computer program MINIQUAD-75 [49]. The stoichiometry and stability constants of the complexes formed were determined by trying various possible composition models. The model selected gave the best statistical fit and was chemically consistent with the titration data without giving any systematic drifts in the magnitudes of various residuals, as described elsewhere [49]. The fitted model was tested by comparing the experimental titration data points and the theoretical curve calculated from the values of the acid dissociation constant of the ligand and the formation constants of the corresponding complexes.

\section{Results and discussion}

\subsection{Elemental analysis}

The elemental analysis data of the mixed-ligand complexes are given in Table 1. The analytical data of the complexes show the formation of 1:1:1 [M: 1,10-phen: ATS] ratio, where $M$ represents $\mathrm{Cu}(\mathrm{II}), \mathrm{Ni}(\mathrm{II}), \mathrm{Zn}(\mathrm{II})$ and $\mathrm{Co}(\mathrm{II})$ ions, ATS, represents the deprotonated Schiff base while 1,10-phen represents the neutral bidentate 1,10-phenanthroline. The analytical data of the metal complexes with the stoichiometries proposed are summarized in Table 1 . The isolated solid complexes are stable in air. The molar conductance indicates that all the complexes are electrolytic in nature. Elemental analyses data were in a good agreement with those required for the suggested formula.

\subsection{IR spectra and mode of bonding}

The IR spectral data for the complexes are summarized in Table 2, together with assignments for most of the major peaks. In order to study the binding mode of the Schiff base ligand to the metal ions in complexes, the IR spectrum of the free Schiff base ligand was compared with the spectra of the complexes. 
Table 3. Molar conductance, magnetic moment and electronic spectral data of mixed-ligand complexes.

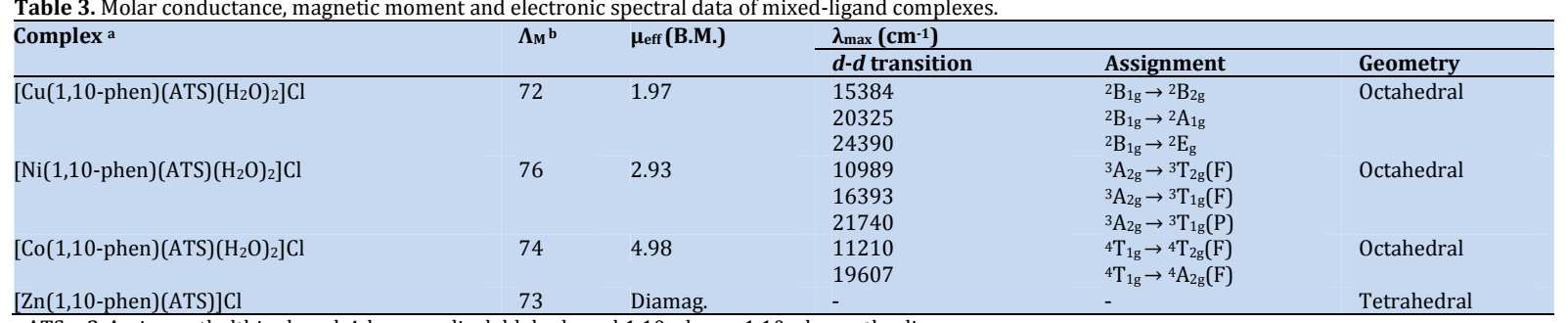

a ATS = 2-Aminomethylthiophenyl-4-bromosalicylaldehyde and 1,10-phen = 1,10-phenanthroline.

b Molar conductance measured for $10^{-3} \mathrm{M}$ DMSO solution, $\Omega^{-1} \cdot \mathrm{cm}^{2} \cdot \mathrm{mol}^{-1}$.

The IR spectrum of ligand (ATS) reveals a broad band in the $3361-3543 \mathrm{~cm}^{-1}$ region assigned to the to $v(\mathrm{OH})$ group. The disappearance of this band in the spectra of the complexes indicates the deprotonation of the hydroxyl group and coordination through deprotonated phenolic $\mathrm{OH}$ group [50,51]. The band observed for ATS ligand at $1319 \mathrm{~cm}^{-1}$ [52] due to $v$ (C0) stretching frequency (aromatic carbon and phenolic oxygen), shifted to lower frequency by $19-27 \mathrm{~cm}^{-1}$ in the mixed-ligand complexes suggesting involvement of the oxygen atom to the metal ion and formation of $\mathrm{M}-\mathrm{O}$ bond via deprotonation. However, the strong band observed at $1675 \mathrm{~cm}^{-}$ 1 in the free ATS Schiff base ligand is assigned to the azomehtine group vibration. This band is shifted towards lower frequencies by $18-22 \mathrm{~cm}^{-1}$ in the complexes, indicating coordination of the imine nitrogen atom to the metal ion $[53,54]$. In the free Schiff base ligand, the sharp band observed at $825 \mathrm{~cm}^{-1}$ is due to $v(\mathrm{C}-\mathrm{S}-\mathrm{C})$ stretching frequency of thiophene ring. In all complexes, this band remains quite unchanged confirming the noninvolvement of the thiophene sulfur in complex formation [55]. The IR spectrum of the free 1,10-phen ligand shows a very stronger bands at $\sim 1570 \mathrm{~cm}^{-1}$ due to stretching frequency of $\mathrm{C}=\mathrm{N}$ present in 1,10phenanthroline moiety. This band was shifted to lower frequencies in the complexes $\sim 25-28 \mathrm{~cm}^{-1}$, which clearly indicate that the coordination of the two nitrogen atoms of the neutral 1,10-phen ligand to M(III) ion upon complexation. The presence of coordinated water molecules are observed by broad bands around $3390-3595 \mathrm{~cm}^{-1}$; assigned to the symmetric and antisymmetric $-\mathrm{OH}$ stretching modes. This is further confirmed by bands observed at $770-782 \mathrm{~cm}^{-1}[56]$ and each of these bands is assigned to the coordinated water molecules. Two new bands appearing in the low frequency ranges 505-540 and 375-398 $\mathrm{cm}^{-1}$ are assigned to the $v(M-0)$ and $\mathrm{v}(\mathrm{M}-\mathrm{N})$ vibrations [57] respectively, supporting the participation of the nitrogen atom of the azomethine group and oxygen of the $\mathrm{OH}$ group of the ligand in the complexation with metal ions [56]. The values of $v(\mathrm{M}-\mathrm{O})$ and $\mathrm{v}(\mathrm{M}-\mathrm{N})$ follow the order $\mathrm{Cu}>\mathrm{Ni}>\mathrm{Co}>\mathrm{Zn}$, in parallel with the crystal field stabilization energies $[58,59]$.

\subsection{Molar conductance measurements}

The molar conductivities of $1 \times 10^{-3} \mathrm{M}$ of the isolated metal chelate solutions at $25 \pm 1{ }^{\circ} \mathrm{C}$ were measured and the measured values were recorded in Table 3 . It is clear from the conductivity data $\left(72-76 \Omega^{-1} \cdot \mathrm{cm}^{2} \cdot \mathrm{mol}^{-1}\right)$ that the complexes present seem to be electrolytes.

\subsection{Magnetic moment and electronic spectra}

The electronic spectral data along with magnetic susceptibility measurements gave adequate support in establishing the geometry of the metal complexes. The solid reflectance spectra of metal complexes show different bands at different wavelengths, each one is corresponding to certain transition which suggests the geometry of the complex compounds. The magnetic moments of the complexes were measured at room temperature. These data along with the tentative assignments of spectral bands and the magnetic moment values are presented in Table 3 .

\subsubsection{Magnetic moment}

The magnetic susceptibility measurements in the solid state show that the present complexes are paramagnetic at room temperature. For the $\left[\mathrm{Cu}(1,10\right.$-phen $\left.)(\mathrm{ATS})\left(\mathrm{H}_{2} \mathrm{O}\right)_{2}\right]$ complex; the magnetic moment is equal to 1.97 B.M. (Table 3) which assigned to octahedral geometry. $\mathrm{Ni}(\mathrm{II})$ complex gave a magnetic moment of 2.93 B.M. and hence assigned as octahedral, because of the square planar complexes of $\mathrm{Ni}(\mathrm{II})$ are a diamagnetic while tetrahedral complexes have moments in the range 3.20-4.10 B.M. [60]. The Co(II) octahedral complexes generally show magnetic moments $\left(\mu_{\text {eff }}\right)$ between 4.7-5.2 B.M. because of the orbital contribution [60]. Since the orbital contribution of tetrahedral $\operatorname{Co}(\mathrm{II})$ complexes have generally lower magnetic moments ( $\sim 3.87$ B.M.), as compared to that of octahedral complexes ( 4.7-5.2 BM) [61]. Co(II) complex showed a magnetic moment of 4.98 B.M. at room temperature suggesting consistency with its octahedral environment.

\subsubsection{Electronic spectra}

Three spin allowed transitions may be expected for six coordinated copper (II) complex in the visible region and the ${ }^{2} \mathrm{E}_{\mathrm{g}}$ and ${ }^{2} \mathrm{~T}_{2 \mathrm{~g}}$ levels of ${ }^{2} \mathrm{D}$ free ion will split into ${ }^{2} \mathrm{~B}_{1 \mathrm{~g}},{ }^{2} \mathrm{~A}_{1 \mathrm{~g}},{ }^{2} \mathrm{~B}_{2 \mathrm{~g}}$ and ${ }^{2} E_{g}$ levels, respectively. Copper (II) complex spectrum showed three bands at $15384\left(v_{1}\right), 20325\left(v_{2}\right)$ and $24390 \mathrm{~cm}^{-1}\left(v_{3}\right)$, corresponding to the following transitions ${ }^{2} \mathrm{~B}_{1 \mathrm{~g}} \rightarrow{ }^{2} \mathrm{~A}_{1 \mathrm{~g}}\left(\mathrm{~d}_{\mathrm{x} 2-\mathrm{y} 2} \rightarrow\right.$ $\left.\mathrm{d}_{\mathrm{z} 2}\right) v_{1},{ }^{2} \mathrm{~B}_{1 \mathrm{~g}} \rightarrow{ }^{2} \mathrm{~B}_{2 \mathrm{~g}}\left(\mathrm{~d}_{\mathrm{x} 2-\mathrm{y} 2} \rightarrow \mathrm{d}_{\mathrm{zy}}\right) v_{2}$ and ${ }^{2} \mathrm{~B}_{1 \mathrm{~g}} \rightarrow{ }^{2} \mathrm{E}_{\mathrm{g}}\left(\mathrm{d}_{\mathrm{x} 2-\mathrm{y} 2} \rightarrow \mathrm{d}_{\mathrm{zy}}\right.$, $d_{y z}$ ) $v_{3}$ (Table 3 ) and this is consistent with an octahedral configuration [7]. The solid reflectance spectrum of the [Ni(1,10-phen)(ATS $\left.\left(\mathrm{H}_{2} \mathrm{O}\right)_{2}\right] \mathrm{Cl}$ complex shows three bands in the near IR-visible region at $v_{1}=10989 \mathrm{~cm}^{-1}\left[{ }^{3} \mathrm{~A}_{2 \mathrm{~g}} \rightarrow{ }^{3} \mathrm{~T}_{2 \mathrm{~g}}\right], v_{2}=$ $16393 \mathrm{~cm}^{-1}\left[{ }^{3} \mathrm{~A}_{2 \mathrm{~g}} \rightarrow{ }^{3} \mathrm{~T}_{1 \mathrm{~g}}(\mathrm{~F})\right]$ and $v_{3}=21740 \mathrm{~cm}^{-1}\left[{ }^{3} \mathrm{~A}_{2 \mathrm{~g}} \rightarrow\right.$ $\left.{ }^{3} \mathrm{~T}_{1 \mathrm{~g}}(\mathrm{P})\right]$. These frequencies are well within the range expected for octahedral $\mathrm{Ni}(\mathrm{II})$ complexes $[7,61]$. The $\mathrm{Co}(\mathrm{II})$ complexes generally give rise to three absorption bands in the visible region under the influence of the octahedral field by the excitation of the electron from the ground state ${ }^{4} \mathrm{~T}_{1 \mathrm{~g}}(\mathrm{~F})$ to the excited states ${ }^{4} \mathrm{~T}_{2 \mathrm{~g}}(\mathrm{~F}),{ }^{4} \mathrm{~A}_{2 \mathrm{~g}}(\mathrm{~F})$ and ${ }^{4} \mathrm{~T}_{1 \mathrm{~g}}(\mathrm{P})$. In the $[\mathrm{Co}(1,10-$ phen)(ATS) $\left.\left(\mathrm{H}_{2} \mathrm{O}\right)_{2}\right] \mathrm{Cl}$ complex, only two bands are observed at $11210 \mathrm{~cm}^{-1}{ }^{4} \mathrm{~T}_{1 \mathrm{~g}}(\mathrm{~F}) \rightarrow{ }^{4} \mathrm{~T}_{2 \mathrm{~g}}(\mathrm{~F})\left(\mathrm{v}_{1}\right)$ and $19607 \mathrm{~cm}^{-1}{ }^{4} \mathrm{~T}_{1 \mathrm{~g}}(\mathrm{~F}) \rightarrow$ ${ }^{4} \mathrm{~T}_{1 \mathrm{~g}}$ (P) $\left(\mathrm{v}_{3}\right)$ as reported in many octahedral cobalt(II) complexes. The $v_{2}$ transition was not observed due to very weak intensity $[7,62]$. No d-d transitions are expected for $\mathrm{d}^{10}$ $\mathrm{Zn}$ (II) complexes. In analogy with those described for Zn(II) complexes containing $\mathrm{N}-\mathrm{O}$ donors $[63,64]$ and according to the empirical formula of $\mathrm{Zn}$ (II) complex, it is likely to be tetrahedral in accordance with the preference of $\mathrm{Zn}$ (II) for tetrahedral coordination [65]. 


\subsection{ESR spectrum of $\left[\mathrm{Cu}(1,10-\right.$ phen $\left.)(\mathrm{ATS})\left(\mathrm{H}_{2} \mathrm{O}\right)_{2}\right]$ complex}

The ESR spectra of complexes provide information about hyperfine and super hyperfine structures which are important in studying the metal ion environment in the complexes, i.e., the geometry, nature of the ligation sites from the ligand to the metal and the degree of covalency of the metal ligand bonds. To obtain further information about the stereochemistry and the site of the metal ligand bonding and to determine the magnetic interaction in the metal complexes, ESR spectra of the complexes were recorded in the solid state. g-Tensor values of copper(II) complexes can be used to derive the ground state, thus, the room temperature powder ESR spectrum of $[\mathrm{Cu}(1,10-$ phen)(ATS) $\left.\left(\mathrm{H}_{2} \mathrm{O}\right)_{2}\right]$ was investigated. It exhibits an axial signal with two g values $\left(g_{\|}=2.141, g_{\perp}=2.035\right)$. In axially elongated octahedral and square planar complexes, the unpaired electron occupies the $d_{\mathrm{x} 2-\mathrm{y} 2}$ orbital with ${ }^{2} \mathrm{~B}_{1 \mathrm{~g}}$ ground state resulting in $\mathrm{g}_{\|}$ $>\mathrm{g}_{\perp}$. However, in a compressed octahedron the unpaired electron occupies the $d_{\mathrm{z} 2}$ orbital with ${ }^{2} \mathrm{~A}_{1 \mathrm{~g}}$ ground state having $\mathrm{g}_{\perp}>\mathrm{g}_{\|}$. The observed " $\mathrm{g}$ " values suggest that the unpaired electron lies predominantly in the $d_{\mathrm{x} 2 \mathrm{y} 2}$ orbital. Therefore the trend $\mathrm{g}_{\|}>\mathrm{g}_{\perp}>\mathrm{g}_{\mathrm{e}}$ (2.0023) observed for this complex indicating that $d_{\mathrm{x} 2-\mathrm{y} 2}$ is the ground state with the $d^{9}[\mathrm{Cu}(\mathrm{II})]$ octahedral geometry around the copper(II) ion [66] in the complex. Kivelson and Neiman [67] have reported that $\mathrm{g}_{\|}<2.3$ and $\mathrm{g}_{\|}>$ 2.3 is characteristic for covalent and ionic characters, respectively. By applying this criterion, the $\mathrm{Cu}(\mathrm{II})$-complex under study has mainly covalent metal-ligand bonding. The G factor $\left(g_{\|}-2.0023 / g_{\perp}-2.0023\right)$ is 4.24 , suggesting that the local tetragonal axes are only slightly misaligned and the exchange interactions between $\mathrm{Cu}(\mathrm{II})$ ions are negligible $[68,69]$.

\section{6. ${ }^{1}$ H NMR spectral studies}

The ${ }^{1} \mathrm{H}$ NMR spectra of ATS Schiff base shows one singlet at $13.17 \mathrm{ppm}$ (Table 4) corresponding to phenolic $-\mathrm{OH}$ proton and one singlet at $8.67 \mathrm{ppm}$ corresponding to azomethine proton ($\mathrm{CH}=\mathrm{N}-)$ [70]. Additionally, the ${ }^{1} \mathrm{HNMR}$ spectra of ATS-Schiff base ligand revealed a multiplet at 7.47-7.72 ppm corresponding to aromatic protons [71]. The spectrum of $\mathrm{Zn}$ (II) complex was compared with that of the parent Schiff base. The signal of the $-\mathrm{OH}$ proton in the spectrum of ATS Schiff base is completely absent in the isolated Zn(II) complex, indicating the release of the $-\mathrm{OH}$ proton and involvement of the $\mathrm{OH}$ group in chelation with the formation of Metal-0 bond. This is in accordance with what the IR data have revealed.

Table 4. ${ }^{1} \mathrm{H}$ NMR data for the free Schiff base ligand and its Zn(II) complex.

\begin{tabular}{lll}
\hline Compound * & 1H NMR assignment & $\mathbf{\Delta , ~ p p m ~}$ \\
\hline ATS & $(\mathrm{s}, 1 \mathrm{H}, \mathrm{OH})$ & 13.17 \\
& $(\mathrm{~s}, 1 \mathrm{H}$, azomethine-H) & 8.67 \\
& $\left(\mathrm{~s}, 2 \mathrm{H},-\mathrm{CH}_{2}-\mathrm{N}=\right)$ & 4.96 \\
& $(\mathrm{~m}, 3 \mathrm{ArH}, 3-$ thiophene $\mathrm{H})$ & $7.47-7.72$ \\
\hline [Zn(1,10-phen)(ATS)]Cl & $(\mathrm{s}, 1 \mathrm{H}$, azomethine-H) & 8.22 \\
& $\left(\mathrm{~s}, 2 \mathrm{H},-\mathrm{CH}_{2}-\mathrm{N}=\right)$ & 4.77 \\
& $(\mathrm{~m}, 3 \mathrm{ArH}, 3-$ thiophene $\mathrm{H})$ & $7.19-7.33$ \\
\hline
\end{tabular}

*ATS = 2-Aminomethylthiophenyl-4-bromosalicylaldehyde and 1,10-phen = 1,10-phenanthroline.

\subsection{Molecular modeling}

The geometry of the studied M(II) complexes has been fully optimized at the DFT B3LYP level of theory using a basis set of a double zeta quality, namely the Lanl2dz basis set. All geometric parameters were allowed to relax without any constrains. All metal complexes studied collapse into an octahedral geometry except the $\mathrm{Zn}(\mathrm{II})$ complex where the octahedral structure is far less stable than the tetrahedral one. The possibility of a pyramidal structure for Zn(II) complex has also been explored, yet this structure is much less stable than the tetrahedral one. Steric effects play a dominant role in this respect. Table 5 presents some selected $\mathrm{M}-\mathrm{X}(\mathrm{M}=\mathrm{Cu}(\mathrm{II}), \mathrm{Ni}(\mathrm{II})$,
Co(II) and $\mathrm{Zn}(\mathrm{II})$ and $\mathrm{X}=\mathrm{N} 12, \mathrm{~N} 24, \mathrm{O}, \mathrm{H}_{2} \mathrm{O}$ and $\mathrm{N} 3$ ) bond lengths for the studied series of complexes. The symmetric nature of the complexes seems preserved within the supramolecular framework. The fact that the $\mathrm{M}-\mathrm{OH}_{2}$ bond length is approximately equal to that of the other $\mathrm{M}-\mathrm{X}$ bond lengths indicate clearly that no Jahn-Teller effects will be observed in the spectra of the studied series of complexes. The net natural charge on the central metal ion in the studied complexes is presented in Table 6 . Figure 2 presents the optimized octahedral structure of the Co(II) complex as a representative example of octahedral geometry and the numbering system adopted in the present work. The two possible structures of the $\mathrm{Zn}(\mathrm{II})$ complex are displayed in Figure 3.

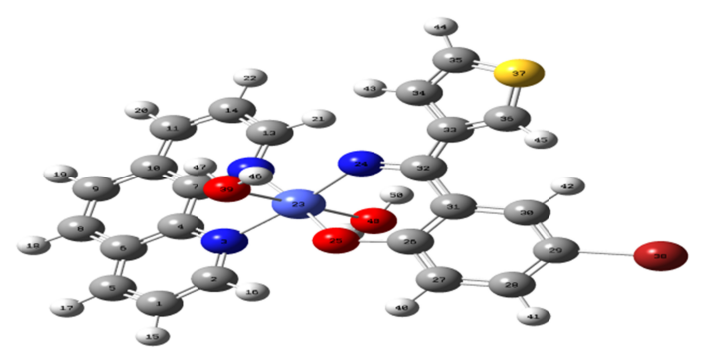

Figure 2. Octahedral structure of Co(II) complex and numbering system adopted in the present work.

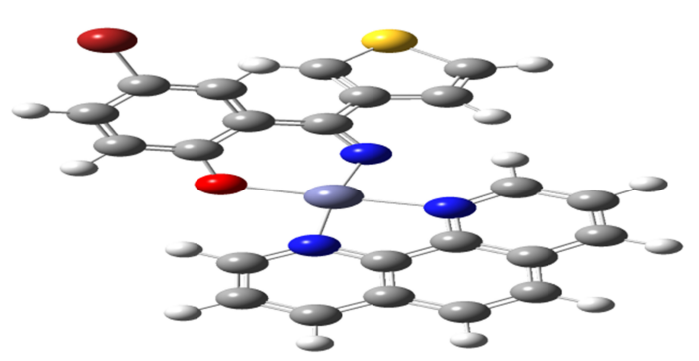

(a)

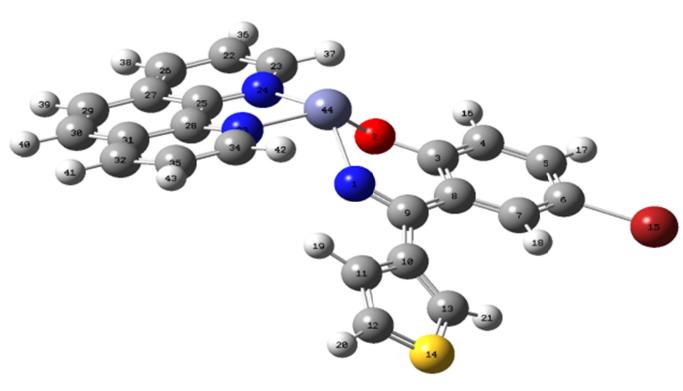

(b)

Figure 3. $\mathrm{Zn}(\mathrm{II})$ complex may adopt (a) tetrahedral or (b) pyramidal structures.

\subsection{Solution equilibrium studies}

Equilibrium studies are carried out in nonaqueous media because of the nature of the compound involved and their insolubility in water. The mixture DMSO:water (7:3) was the chosen solvent for our study. The use of this mixed solvent has some advantages over pure DMSO. Thus, pure DMSO is very hygroscopic and controlling its water content is difficult [71]. This fact would affect reproducibility of our experiment. However, DMSO:water (7:3) mixture has only small hygroscopic character. 
Table 5. Some selected geometric parameters $(\AA)$ for the studied M(II) complexes.

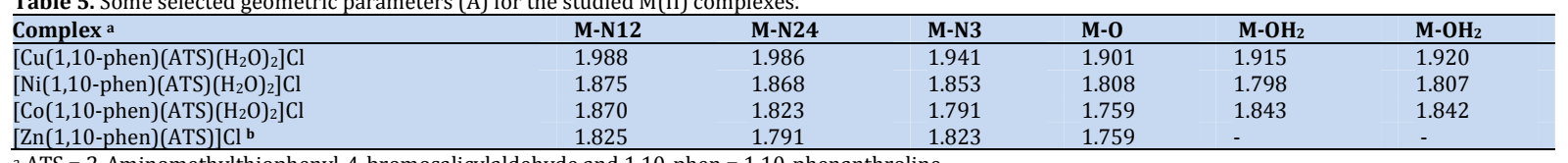

a ATS = 2-Aminomethylthiophenyl-4-bromosalicylaldehyde and 1,10-phen = 1,10-phenanthroline.

b Tetrahedral for Zn(II)-complex.

Table 6. Natural charge and the electron configuration adopted by the central metal ion in the synthesized complexes.

\begin{tabular}{|c|c|c|c|c|c|c|}
\hline Complex a & Charge & Core & Valence & Rydberg & Total & Configuration \\
\hline$\left[\mathrm{Cu}(1,10\right.$-phen $\left.)(\mathrm{ATS})\left(\mathrm{H}_{2} \mathrm{O}\right)_{2}\right] \mathrm{Cl}$ & 0.78805 & 17.995 & 10.207 & 0.0108 & 28.212 & [core] $4 \mathrm{~s}(0.28), 3 \mathrm{~d}(9.38), 4 \mathrm{p}(0.19), 5 \mathrm{p}(0.36)$ \\
\hline$\left[\mathrm{Ni}(1,10\right.$-phen $\left.)(\mathrm{ATS})\left(\mathrm{H}_{2} \mathrm{O}\right)_{2}\right] \mathrm{Cl}$ & 0.67153 & 17.991 & 9.3199 & 0.0172 & 27.328 & [core] $4 \mathrm{~s}(0.28), 3 \mathrm{~d}(8.47), 4 \mathrm{p}(0.57), 4 \mathrm{~d}(0.01), 5 \mathrm{p}(0.01)$ \\
\hline$\left[\mathrm{Co}(1,10\right.$-phen $\left.)(\mathrm{ATS})\left(\mathrm{H}_{2} \mathrm{O}\right)_{2}\right] \mathrm{Cl}$ & 0.42880 & 17.989 & 8.557 & 0.025 & 26.571 & [core] $3 \mathrm{~d}(7.75), 4 \mathrm{p}(0.37), 5 \mathrm{~s}(0.27), 4 \mathrm{~d}(0.02), 5 \mathrm{p}(0.17)$ \\
\hline$[\mathrm{Zn}(1,10 \text {-phen })(\mathrm{ATS})]_{\mathrm{Cl}}^{\mathbf{b}}$ & 1.24879 & 18.000 & 10.742 & 0.0096 & 28.751 & [core] $4 \mathrm{~s}(0.31), 3 \mathrm{~d}(9.94), 4 \mathrm{p}(0.50)$ \\
\hline
\end{tabular}

a ATS = 2-Aminomethylthiophenyl-4-bromosalicylaldehyde and 1,10-phen = 1,10-phenanthroline.

b Tetrahedral for Zn(II)-complex.

Table 7. Stability constants $(\log \beta)$ of binary species in the M(II)-ATS $25^{\circ} \mathrm{C}$ and $0.1 \mathrm{~mol} / \mathrm{dm}^{3}$ ionic strength using NaCl.

\begin{tabular}{|c|c|c|c|c|c|}
\hline Compound a & p & $\mathbf{q}$ & $\mathbf{r}^{\mathbf{b}}$ & $\log \beta \pm \sigma^{c}$ & $S$ d \\
\hline \multirow[t]{2}{*}{ ATS } & 0 & 1 & 1 & $10.12 \pm 0.02$ & $1.9 \times 10^{-8}$ \\
\hline & 0 & 1 & 2 & $17.73 \pm 0.01$ & \\
\hline \multirow[t]{2}{*}{$\mathrm{Cu}(\mathrm{II})-\mathrm{ATS}$} & 1 & 1 & 0 & $9.64 \pm 0.03$ & $2.5 \times 10^{-7}$ \\
\hline & 1 & 2 & 0 & $16.68 \pm 0.02$ & \\
\hline \multirow[t]{2}{*}{ Ni(II)-ATS } & 1 & 1 & 0 & $7.11 \pm 0.04$ & $2.9 \times 10^{-7}$ \\
\hline & 1 & 2 & 0 & $12.29 \pm 0.06$ & \\
\hline \multirow[t]{2}{*}{ Co(II)-ATS } & 1 & 1 & 0 & $6.60 \pm 0.02$ & $5.3 \times 10^{-7}$ \\
\hline & 1 & 2 & 0 & $11.13 \pm 0.05$ & \\
\hline \multirow[t]{2}{*}{$\mathrm{Zn}(\mathrm{II})-\mathrm{ATS}$} & 1 & 1 & 0 & $6.29 \pm 0.03$ & $9.1 \times 10^{-7}$ \\
\hline & 1 & 2 & 0 & $10.62 \pm 0.07$ & \\
\hline
\end{tabular}

a ATS = 2-Aminomethylthiophenyl-4-bromosalicylaldehyde.

${ }^{\mathrm{b}} \mathrm{p}$, $\mathrm{q}$ and $\mathrm{r}$ are stoichiometric coefficients corresponding to $\mathrm{M}(\mathrm{II}), \mathrm{ATS}$, and $\mathrm{H}^{+}$, respectively.

c Standard deviation.

d Sum of square of residuals.

Table 8. Antibacterial activity of bivalent transition metal ion mixed-ligandransition metal complexes.

\begin{tabular}{|c|c|c|c|c|}
\hline \multirow[t]{3}{*}{ Complexes a } & \multicolumn{4}{|c|}{ Diameter of inhibition zone (in mm) b/ (MIC) c } \\
\hline & \multicolumn{2}{|c|}{ G- } & \multicolumn{2}{|l|}{$\mathbf{G}^{+}$} \\
\hline & Shigella flexneri & Proteous vulgaris & Bacillus subtillis & Staphylococcus aureus \\
\hline$\left[\mathrm{Cu}(1,10\right.$-phen $\left.)(\mathrm{ATS})\left(\mathrm{H}_{2} \mathrm{O}\right)_{2}\right] \mathrm{Cl}$ & $17.7 \pm 0.67(31.25)$ & $18.4 \pm 0.53(7.81)$ & $20.4 \pm 0.38(7.81)$ & $22.3 \pm 0.56(3.91)$ \\
\hline$\left[\mathrm{Ni}(1,10\right.$-phen $\left.)(\mathrm{ATS})\left(\mathrm{H}_{2} \mathrm{O}\right)_{2}\right] \mathrm{Cl}$ & $16.4 \pm 0.43(62.5)$ & $15.3 \pm 0.32(62.5)$ & $12.4 \pm 0.58(62.25)$ & $14.2 \pm 0.29(25.97)$ \\
\hline$\left[\mathrm{Co}(1,10\right.$-phen $\left.)(\mathrm{ATS})\left(\mathrm{H}_{2} \mathrm{O}\right)_{2}\right] \mathrm{Cl}$ & - & $13.4 \pm 0.63(125)$ & $15.5 \pm 0.25(12.5)$ & $13.9 \pm 0.29(62.5)$ \\
\hline$[\mathrm{Zn}(1,10$-phen $)(\mathrm{ATS})] \mathrm{Cl}$ & $22.7 \pm 0.31(0.48)$ & $23.6 \pm 0.39(9.9)$ & $24.7 \pm 0.28(0.06)$ & $25.8 \pm 0.19(0.24)$ \\
\hline Gentamicin and Ampicillin (Standard) $\mathrm{d}$ & $24.8 \pm 0.24(0.48)$ & $23.4 \pm 0.3(1.95)$ & $34.6 \pm 0.35(0.007)$ & $28.9 \pm 0.14(0.06)$ \\
\hline
\end{tabular}

a ATS = 2-Aminomethylthiophenyl-4-bromosalicylaldehyde and 1,10-phen = 1,10-phenanthroline.

b Mean zone of inhibition in $\mathrm{mm} \pm$ standard deviation.

c Minimium inhibitory concentration $(\mu \mathrm{g} / \mathrm{mL})$ of tested samples against tested microorganisms, "-" : no activity.

dStandard discs of Gentamicin for $\mathrm{G}^{-}$and Ampicillin for $\mathrm{G}^{+}$are used as antibacterial agents.

A further advantage is its compatibility with the standard glass electrode, so that the $\mathrm{pH}$ measurements may be carried out in a similar way to that employed in a purely aqueous solution. In contrast, the use of pure DMSO is not recommended for potentiometry. Another advantage of the DMSO:water (7:3) mixture is its large acidity range $\left(\mathrm{pK}_{\mathrm{w}}=15.75\right)$ which allows the investigation of deprotonation equilibria of weak acids which could be hardly studied in water [72,73]. The equilibrium studies were determined in 70\% DMSO-water mixture at $25{ }^{\circ} \mathrm{C}$ and these constants are tabulated in Table 7. Analysis of the potentiometric titration curve using the program Miniquad-75 gave best fit for two protonation constants (Table 7) for the Schiff-base ligand. Potentiometric titrations of ATS with $\mathrm{Zn}(\mathrm{II}), \mathrm{Cu}(\mathrm{II}), \mathrm{Ni}(\mathrm{II})$ and $\mathrm{Co}(\mathrm{II})$ ions were carried out in 1:1 and 1:2 metal-ligand molar ratios at $\mathrm{I}=0.1 \mathrm{M}$ $\mathrm{NaCl}$ and $25^{\circ} \mathrm{C}$ in DMSO:water $(7: 3)$ mixture. The deviation in the metal-ligand titration curves from the ligand titration curve implies the formation of metal complexes. The overall formation constants $(\log \beta)$ of the species were calculated using Miniquad-75 program (Table 7).

The complex forming ability of the transition metal ions are frequently characterizes by stability orders. It can be seen that $\log \mathrm{K}$ arranged in the order $\mathrm{Zn}(\mathrm{II})<\mathrm{Cu}$ (II) $>\mathrm{Ni}$ (II) $>\mathrm{Co}$ (II) is in accordance with Irving-William's order for divalent metals of $3 \mathrm{~d}$ series [74]. In general, it is noted that the stability constant of the $\mathrm{Cu}(\mathrm{II})$ complex is quite large compared to the other metals. The ligand field will give $\mathrm{Cu}(\mathrm{II})$ some extra stabilization due to tetragonal distortion of the octahedral symmetry [75].

\subsection{Biological activity}

\subsubsection{Antibacterial and antifungal activities}

The metal complexes were tested for their inhibitory effects on the growth of Staphylococcus aureus, Bacillus subtillis, Shigella flexneri, Proteous vulgaris bacteria because bacteria can achieve resistance to antibiotics through biochemical and morphological modifications [76]. The antibacterial and antifungal activities of the new compounds are presented in Tables 8 and 9 respectively. It is observed that the activity of ternary complexes is more compared to their corresponding binary complexes [20]. This result is expected since the complexes possess a greater planar area and $\pi$-systems which make stacking more strongly. The biological activity of complexes may be arise from the hydroxyl groups which may play an important role in the antibacterial activity [77], as well as the presence of imine group which imports in elucidating the mechanism of transformation reaction in biological systems [78]. The antimicrobial activity can be ordered as $[\operatorname{Zn}(1,10-$ phen)(ATS) $]>\left[\mathrm{Cu}(1,10\right.$-phen $)($ ATS $\left.)\left(\mathrm{H}_{2} \mathrm{O}\right)_{2}\right]>[\mathrm{Ni}(1,10-$ phen)(ATS) $\left.\left(\mathrm{H}_{2} \mathrm{O}\right)_{2}\right]>\left[\mathrm{Co}(1,10\right.$-phen $\left.)(\mathrm{ATS})\left(\mathrm{H}_{2} \mathrm{O}\right)_{2}\right]$ (Figure 4), suggesting that the lipophilic behavior increases in the same order. 
Table 9. Antifungal activity of mixed-ligand complexes.

\begin{tabular}{|c|c|c|}
\hline \multirow[t]{2}{*}{ Complex a } & \multicolumn{2}{|c|}{ Diameter of inhibition zone (in $\mathrm{mm}$ ) $\mathrm{b} /(\mathrm{MIC})^{\mathrm{c}}$} \\
\hline & Aspergillus fumigatus & Candida albicans \\
\hline$\left[\mathrm{Cu}(1,10\right.$-phen $\left.)(\mathrm{ATS})\left(\mathrm{H}_{2} \mathrm{O}\right)_{2}\right] \mathrm{Cl}$ & $20.3 \pm 0.35(7.81)$ & $17.8 \pm 0.23(3.90)$ \\
\hline$\left[\mathrm{Ni}(1,10\right.$-phen $\left.)(\mathrm{ATS})\left(\mathrm{H}_{2} \mathrm{O}\right)_{2}\right] \mathrm{Cl}$ & $16.7 \pm 0.23(15.63)$ & $13.8 \pm 0.53(15.63)$ \\
\hline$\left[\mathrm{Co}(1,10\right.$-phen $\left.)(\mathrm{ATS})\left(\mathrm{H}_{2} \mathrm{O}\right)_{2}\right] \mathrm{Cl}$ & $15.7 \pm 0.23(62.5)$ & $12.2 \pm 0.36(31.26)$ \\
\hline$[\mathrm{Zn}(1,10$-phen $)(\mathrm{ATS})] \mathrm{Cl}$ & $21.4 \pm 0.53(7.81)$ & $20.3 \pm 0.24(1.95)$ \\
\hline Amphotericin B (Standard) d & $23.7 \pm 0.10(0.97)$ & $26.4 \pm 0.20(0.48)$ \\
\hline
\end{tabular}

a ATS = 2-Aminomethylthiophenyl-4-bromosalicylaldehyde and 1,10-phen = 1,10-phenanthroline.

b Mean zone of inhibition in $\mathrm{mm} \pm$ standard deviation.

c Minimium inhibitory concentration $(\mu \mathrm{g} / \mathrm{mL})$ of tested samples against tested microorganisms.

dStandard discs of Amphotericin B is used as antifungal agent.

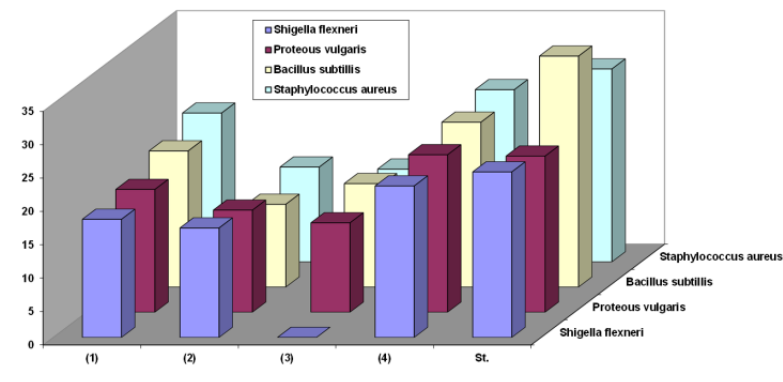

Figure 4. Antibacterial activity of mixed-ligand complexes.

Since all complexes (i) have the same donating atoms which are N/O, (ii) have the same chelate effect (all form two five and six-membered chelating rings), (iii) have the same charge and the same counter ion, and (iv) have the same oxidation number in their complexes (M(II)), therefore, the more effective factors are the geometrical shape and the nature of the central atoms. According to the spectral and magnetic studies, (i) zinc has a tetrahedral geometry; (ii) copper; cobalt and nickel have octahedral structure. Therefore, the higher antimicrobial activity of Zn(II) complex can be referred to its structure which is the tetrahedral. Comparison of the biological activity of the synthesized compounds with Amphotericin B shows generally the complexes exhibit better activity or have a comparable effect. The synthesized Zn(II) complex is active against Candida albicans with MIC value of $1.95 \mu \mathrm{g} / \mathrm{mL}$ versus candida albicans. The antifungal activity was given in Figure 5. The tested complexes were more active against Gram-positive than Gramnegative bacteria, it may be concluded that the antimicrobial activity of the compounds is related to cell wall structure of the bacteria. Gram-positive bacteria possess a thick cell wall containing many layers of peptidoglycan and teichoic acids, but in contrast, Gram negative bacteria have a relatively thin cell wall consisting of a few layers of peptidoglycan. These differences in cell wall structure can produce differences in antibacterial susceptibility and some antibiotics can kill only Gram-positive bacteria and is infective against Gram-negative pathogens $[7,20,28,79-81]$.

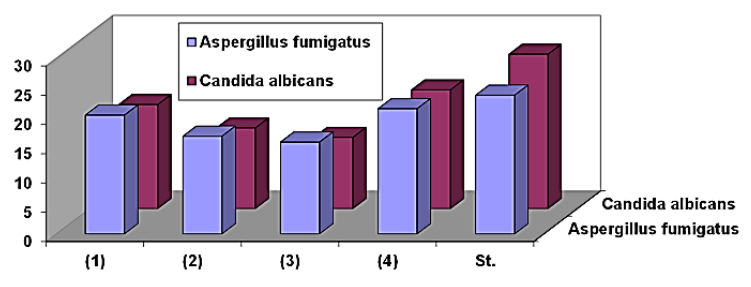

Figure 5. Antifungal activity of mixed-ligand complexes.

\subsubsection{Cytotoxic activities}

In vitro potential cytotoxicity of $\mathrm{Cu}(\mathrm{II}), \mathrm{Ni}(\mathrm{II})$ and $\mathrm{Zn}(\mathrm{II})$ complexes was tested against colon carcinoma (HCT116) and larynx carcinoma (HEP2) cells. The relation between surviving fraction and drug concentration is plotted to get the survival curve of each tumor cell line, Figure 6, $\mathrm{IC}_{50}$ values are cited in Table 10. Cytotoxic study of the compounds against colon carcinoma (HCT116) and larynx carcinoma (HEP2) cells indicate that, $\left[\mathrm{Cu}(1,10-\right.$ phen $\left.)(\mathrm{ATS})\left(\mathrm{H}_{2} \mathrm{O}\right)_{2}\right]$ and $[\mathrm{Zn}(1,10-$ phen)(ATS)]complexes show significant activity against larynx cancer cells with $\mathrm{IC}_{50}$ values of 0.56 and $0.45 \mu \mathrm{g} / \mathrm{mL}$, respectively (Figure 6) classifying these compounds as chemotherapeutically significant. $\mathrm{IC}_{50}$ is the concentration which can reduce the growth of cancer cells by $50 \%$. The rank order of potency as a function of chelated metal ion follows the order $\mathrm{Co}<\mathrm{Ni}<\mathrm{Cu}<\mathrm{Zn}$ against HEP2 cancer cells. Results show that the growth inhibition of tumor cells is due to apoptosis in metal complexes. In conclusion, the Zn-complex exhibits significant decrease in surviving fraction of HCT116 and HEP2 cancer cells and induced apoptosis of these cell lines.
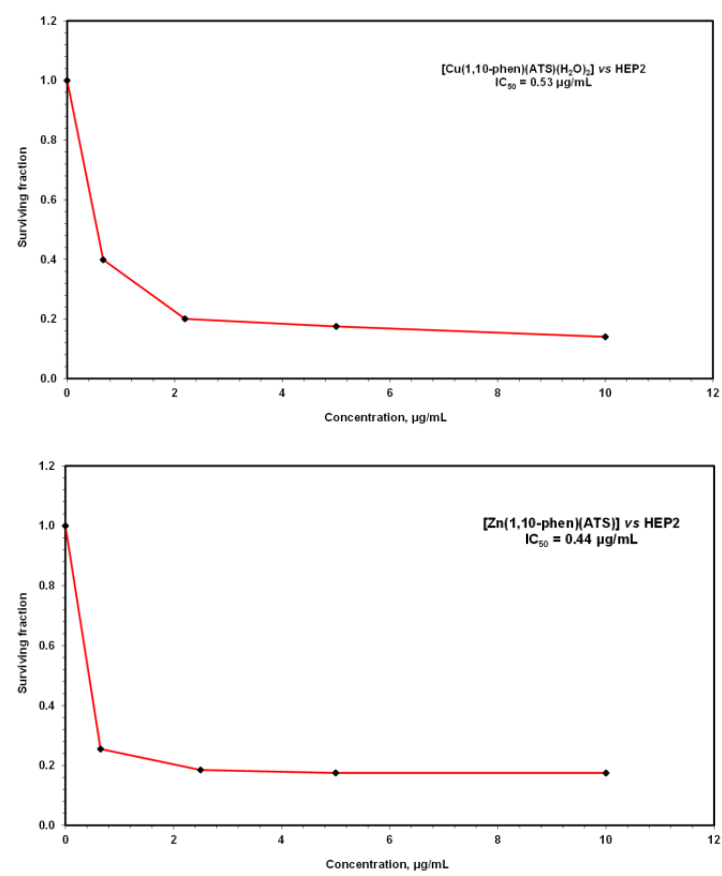

Figure 6. Effect of $\left[\mathrm{Cu}(1,10\right.$-phen $\left.)(\mathrm{ATS})\left(\mathrm{H}_{2} \mathrm{O}\right)_{2}\right]$ and $[\mathrm{Zn}(1,10$-phen)(ATS)] complexes on surviving fraction of HEP2 tumor cells.

\subsection{Structure of the complexes}

Single crystals of the complexes could not be isolated from any solutions; thus, no definitive structure can be described. However, it is concluded that from elemental analysis, IR and ${ }^{1} \mathrm{H}$ NMR spectra, the Schiff base ligand (ATS) behaves as a bidentate ligand coordinated to the metal ions $\mathrm{Cu}(\mathrm{II}), \mathrm{Ni}(\mathrm{II})$, Co(II) and Zn(II) through the phenolate oxygen and azomethine group while 1,10-phen acts as a neutral bidentate ligand coordinated through the pyridine nitrogen atoms (Figure 7). 
Table 10. Effect of synthesized metal complexes on tumor cell growth in vitro ( $\mathrm{IC}_{50}$ values in $\mu \mathrm{g} / \mathrm{mL}$ ).

\begin{tabular}{|c|c|c|}
\hline \multirow[t]{2}{*}{ Compounds a } & \multicolumn{2}{|l|}{$\mathrm{IC}_{50} \mathrm{~b}^{\mathrm{b}}$} \\
\hline & HCT116 & HEP2 \\
\hline$\left[\mathrm{Cu}(1,10\right.$-phen $\left.)(\mathrm{ATS})\left(\mathrm{H}_{2} \mathrm{O}\right)_{2}\right] \mathrm{Cl}$ & 1.73 & 0.53 \\
\hline$\left[\mathrm{Ni}(1,10\right.$-phen $\left.)(\mathrm{ATS})\left(\mathrm{H}_{2} \mathrm{O}\right)_{2}\right] \mathrm{Cl}$ & 1.92 & 0.62 \\
\hline$\left[\mathrm{Co}(1,10\right.$-phen $\left.)(\mathrm{ATS})\left(\mathrm{H}_{2} \mathrm{O}\right)_{2}\right] \mathrm{Cl}$ & 2.21 & 0.77 \\
\hline$[\mathrm{Zn}(1,10$-phen $)(\mathrm{ATS})] \mathrm{Cl}$ & 1.28 & 0.44 \\
\hline Doxorubicin (Standard) & 0.69 & 0.40 \\
\hline
\end{tabular}

a ATS = 2-Aminomethylthiophenyl-4-bromosalicylaldehyde and 1,10-phen = 1,10-phenanthroline.

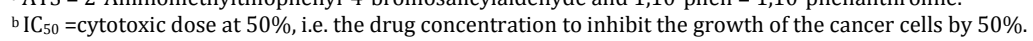

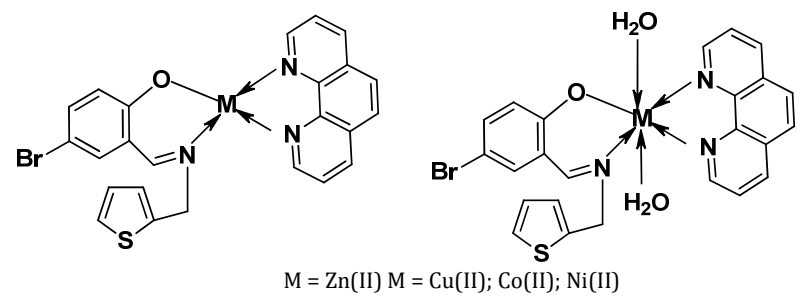

Figure 7. Suggested structure of the mixed-ligand M(II) complexes.

On the basis of the elemental analysis and spectral data octahedral geometry is suggested for all investigated complexes except $\mathrm{Zn}(\mathrm{II})$ complex is a tetrahedral

\section{Conclusions}

The present paper reports on the synthesis, characterization and biological activity of [M(1,10-phen)(ATS) $\left(\mathrm{H}_{2} \mathrm{O}\right)_{2}$ ] complexes. The synthetic procedure in this work resulted in the formation of complexes in the molar ratio (1:1:1) (M : 1,10-phen : ATS) respectively. From the molar conductance data, it was found that all the M(II) chelates are considered as 1:1 electrolytes. On the basis of the analytical, conductivity, magnetic data, infrared, molecular modeling and electronic spectral data, octahedral geometry were concluded for all investigated complexes except $\mathrm{Zn}$ (II) complex is a tetrahedral. Based on these observations, metal ion coordinates through phenolate oxygen, azomethine nitrogen of Schiff base, and nitrogen atoms of phenanthroline. In the absence of X-ray single crystal data of the current synthesized complexes and based on the physicochemical studies and geometrical optimization, a tentative structure could be proposed as shown in Figs. 1 and 2. The antimicrobial study reveals that some of the synthesized complexes show better activity or comparable activity to the standard drug antibiotic. The metal complexes were more active against Gram-positive (Staphylococcus aureus, Bacillus subtillis) than Gram-negative (Shigella flexneri, Proteous vulgaris) bacteria. The antibacterial activity of mixed ligand complexes is larger than that of ATS binary complexes. Also, the results indicated that tested complexes were more active against Gram-positive than Gram-negative bacteria. It may be concluded that antibacterial activity of the compounds is related to cell wall structure of the bacteria. It is possible because the cell wall is essential to the survival of many bacteria and some antibiotics are able to kill bacteria by inhibiting a step in the synthesis of peptidoglycan. The antitumor activity of complexes displayed good cytotoxic activities against the investigated cancer cell lines. The importance of such kind of work lies in the possibility that the new compounds might be more effective against microbes for which a thorough study regarding the structure-activity relationship.

\section{References}

[1]. Sigman, D. S.; Mazumder, A.; Perrin, D. M.; Wang, M. Z.; Meng, Z. X.; Liu, B. L.; Cai, G. L.; Zhang, C. L.; Wang, X. Y. Inorg. Chem. Commun, 2005, $8(4), 368-371$.
[2]. Sharma, V.; Piwnica-Worms, D. Chem. Rev. 1999, 99(9), 2545-2560.

[3]. Sattari, D.; Alipour, E.; Shirani, S.; Amighian, J. J. Inorg. Biochem. 1992, 45(2), 115-122.

[4]. Hitoshi, T.; Tamao, N.; Hideyuki, A.; Manabu, F.; Takayuki, M. Polyhedron 1997, 16, 3787-3794.

[5]. Casella, L.; Gullotti, M. Inorg. Chem. 1986, 25(9), 1293-1303.

[6]. Casella, L.; Gullotti, M. Inorg. Chem. 1983, 22(16), 2259-2266.

[7]. El-Sherif, A. A.; Shehata, M. R.; Shoukry, M. M.; Barakat, M. H. J. Spectrochim. Acta A 2012, 96, 889-897.

[8]. El-Sherif, A. A.; Shoukry, M. M.; Abd-Elgawad, M. M. A. Spectrochim. Acta A 2012, 98, 307-321.

[9]. Aminabhavi, T. M.; Biradar, N. S.; Patil, S. B.; Roddabasanagoudar, V. L.; Rudzinski, W. E. Inorg. Chim. Acta 1985, 107(4), 231-234.

[10]. Wolfe, A.; Shimer Jr, G. H.; Meehan, T.; Biochem. 1987, 26(20), 63926396.

[11]. Zhang, C.; Janiak, C. J. Chem. Crystllog. 2001, 31(1), 29-35.

[12]. Campbell, M. J. M. Coord. Chem. Rev. 1975, 15, 279-312.

[13]. Williams, D. R. Chem. Rev. 1972, 72, 203-213.

[14]. Furst, A.; Haro, R. T. Prog. Exp. Tumor Res. 1969, 12, 102-133.

[15]. Dwyer, F. B.; Mayhew, E.; Roe, E. M. F.; Shulman, A. Brit. J. Cancer 1965, 19, 195-199.

[16]. Sylvain, R.; Bernier, J. L.; Waring, M. J. J. Org. Chem. 1996, 61, 23262331.

[17]. Gravert, D. J.; Griffin, J. H.; J. Org. Chem. 1993, 58, 820-822.

[18]. Balasubramanian, K. P.; Parameswari, K.; Chinnusamy, V.; Prabhakaran, R; Natarajan, K. Spectrochim. Acta A 2006, 65, 678-683.

[19]. Meyer, R.; Brink, S.; Van Rensburg, C. E. J.; Joone, G. K.; Gorls, H.; Lotz, S. J. Org. Met. Chem. 2005, 690, 117-125.

[20]. El-Sherif, A. A.; Eldebss, T. M. A. Spectrochim. Acta A 2011, 79, 1803 1814.

[21]. Konstantinivi, S. S.; Radovanovi, B. C.; Caki, Z.; Vasic, V. J. Ser. Chem Soc. 2003, 68, 641-648.

[22]. Sammes, P. G.; Yahioglu, G. Chem. Soc. Rev. 1994, 23, 327-334.

[23]. Farrell, N. Transition Metal Complexes as Drugs and Chemotherapeutic Agents, Kluwer Academic, Dordrecht, 1989.

[24]. El-Sherif, A. A. J. Solution Chem. 2006, 35, 1287-1301.

[25]. Mohamed, M. M. A.; El-Sherif, A. A. J. Solution Chem. 2010, 39, 639653.

[26]. El-Sherif, A. A.; Shoukry, M. M. J. Coord. Chem. 2005, 58(16), 14011415.

[27]. El-Sherif, A. A.; Shoukry, M. M. J. Spectrochim. Acta A 2007, 66, 691700.

[28]. El-Sherif, A. A.; Shoukry, M. M. Inorg. Chim. Acta 2007, 360, 473-487.

[29]. El-Sherif, A. A. J. Solution Chem. 2010, 39, 1562-1581.

[30]. El-Sherif, A. A. Inorg. Chim. Acta 2009, 362, 4991-5000.

[31]. Frish, M. J.; Trucks, G. W.; Schlegel, H. B.; Scuseria, G. E.; Robb, M. A. Cheeseman, J. R.; Zakrzewski, V. G.; Gaussian, Inc. , Pittsburgh, PA, 2008.

[32]. Zhang, Q.; Li, Z.; Chen, B. J. Mol. Struct. (Theochem.) 2009, 901, 202210.

[33]. Zhang, Q.; Chen, B. J. Mol. Struct. (Theochem.) 2010, 941, 41-46.

[34]. Smith, D. M.; Nicolaides, A.; Golding, B. T.; Radom, L. J. Am. Chem. Soc. 1998, 120, 10223-10233.

[35]. Dunning, T. H.; Hay, P. J. Modern Theoretical Chemistry, Ed. H. F. Schaefer III, 1976, Vol. 3 (Plenum, New York) 1-28.

[36]. Hay, P. J.; Wadt, W. R. J. Chem. Phys. 1985, 82, 270-283.

[37]. Hay, P. J.; Wadt, W. R. J. Chem. Phys. 1985, 82, 299-310. 
[38]. Ulic, S. E.; Vedova, C. O. D.; Hermann, A.; Mack, H. G.; Oberhammer, H. J. Phys. Chem. A 2008, 112, 6211-6216.

[39]. Bauer, A. W.; Kirby, W. M.; Sherris, C.; Turck, M. J. Am. Clin. Pathol. 1966, 45, 493-496.

[40]. Pfaller, M. A.; Burmeister, L.; Bartlett, M. A.; Rinaldi, M. G. J. Clin. Microbiol. 1988, 261437-1441.

[41]. National Committee for Clinical Laboratory Standards (1993), Methods for dilution antimicrobial susceptibility tests for bacteria that grow aerobically. Approved standard M7-A3, Villanova, Pa.

[42]. L. D. Liebowitz, H. R. Ashbee, E. G. V. Evans, Y. Chong, N. Mallatova, M. Zaidi, D. Gibbs, Microbiol. Infet. Dis. 2001, 24, 27-33.

[43]. National Committee for Clinical Laboratory Standards, Methods for dilution antimicrobial susceptibility tests for bacteria that grow aerobically. Approved standard M7-A3, Villanova, Pa (1993).

[44]. Matar, M. J. , Ostrosky-Zeichner, L. , Paetznick, V. L., Rodriguez, J. R., Chen, E. , Rex, J. H. Antimicrob. Agents Chemother. 2003, 47, 16471651.

[45]. Skehan, P.; Storeng, R.; Scudiero, D.; Monks, A.; McMahon, J.; Vistica, D.; Warren, J. T.; Bokesch, H.; Kenney, S.; Boyd, M. R. J. Nat. Cancer Inst. 1990, 82, 1107-1112.

[46]. Gündüz, T.; Kılıc, E.; Koseoglu, F.; Canel, E. Anal. Chim. Acta 1993, 282, 489-495.

[47]. Van Uitert, G. L.; Hass, C. G. J. Am. Chem. Soc. 1971, 75, 451-455.

[48]. Serjant, E. P.; Potentiometry and Potentiometric Titrations, Wiley, New York, 1984

[49]. Gans, P.; Sabatini, A.; Vacca, A. Inorg. Chim. Acta 1976, 18, 237-239.

[50]. Zaki, Z. M.; Haggag, S. S.; Soayed, A. A. Spectroscopy Lett. 1983, 31(4), 757-766.

[51]. Bellamy, L. J.; The Infrared Spectra of Complex Molecules, second ed., J. Wiley, New York, 1964.

[52]. Sarkar, S.; Dey, K. Spectrochim. Acta A 2005, 62, 383-393.

[53]. West, X.; Nassar, A. A. Trans. Metal Chem. 1998, 23, 321-326.

[54]. Bagihalli, G. B.; Avaji, P. G.; Patil, S. A.; Badami, P. S. Eur. J. Med. Chem. 2008, 43, 2639-2649.

[55]. Gronowitz, S.; Katritsky, A. R.; Reavill, R. E. J. Am. Chem. Soc. 1964, 86, 3881-3882.

[56]. Prashanthi, Y.; Kiranmai, K.; Subhashini, N. J. P. Spectrochim. Acta A 2008, 70, 30-35

[57]. Nakamoto, K. Infrared and Raman Spectra of Inorganic and Coordination Compounds, $5^{\text {th }}$ ed., Part II: Applications in Coordination, Organometallic and Bioinorganic Chemistry, Wiley, New York, 1997.

[58]. Percy, C. G.; Thornton, D. A. J. Inorg. Nucl. Chem. 1973, 35, 2719-2725.

[59]. Hulett, L. G.; Thornton, D. A. Spectrochim. Acta A 1971, 27, 2089-2096.

[60]. Earnshaw, A. The Introduction to Magnetochemistry, Academic Press, London, 1980, p. 80.

[61]. Abrahim, J.; Narayana, B.; Mahadevi, S.; Ramachandra, B. Turk. J. Chem. 1994, 18, 14-19.

[62]. Lever, A. B. P. Crystal Field Spectra. Inorganic Electronic Spectroscopy first ed., Elsevier, Amsterdam, 1968

[63]. Sanmartin, J.; Bermejo, M. R.; Deibe, A. M. G.; Maneiro, M.; Lage, C.; Filho, A. J. C. Polyhedron 2000, 19, 185-192.

[64]. Krzyminiewska, V. P.; Litkowska, H.; Paryzek, W. R. Monatsh Chem. 1999, 130, 243-249.

[65]. Melnik, M.; Gyoryova, K.; Skorsepa, J.; Holloway, C. E. J. Coord. Chem. 1995, 35, 179-185.

[66]. Hathaway, B. J.; Tomlinson, A. A. G. Coord. Chem. Rev. 1970, 5, 1-44.

[67]. Kivelson, D.; Neiman, R. R. J. Chem. Phys. 1961, 35, 149-151.

[68]. Singh, V. Spectrochim. Acta A 2008, 71, 17-23.

[69]. El-Sherif, A. A.; Jeragh, B. J. A. Spectrochim. Acta A 2007, 68, 877-882.

[70]. Rao, S. Asian J. Chem. 2005, 17, 2663-2668.

[71]. Nseimi, H.; Safari, J.; Heidarnezhad, A. Dyes Pigments 2007, 73, 251260.

[72]. Martin, D.; Hauthal, H. G.; Dimethyl Sulphoxide, Van Nostrand Reinhold, Workingham, UK, 1975.

[73]. Hermandez-Molina, R.; Mederos, A.; Gili, P.; Dominquez, S.; Numez, P.; Grmain, G.; Debaerdemaeker, T. Inorg. Chim. Acta 1997, 256, 319-325.

[74]. Irving, H.; Williams, R. J. P. Nature, 1948, 162, 746-747.

[75]. Irving, H.; Williams, R. J. P. J. Chem. Soc. 1953, 8, 3192-3210.

[76]. Cotton, F. A.; Wilkinson. G. Adv. Inorg. Chem. Wiley, London (1962).

[77]. Cakir, S.; Bicer, E.; Odabasoglu, M.; Albayrak, C. J. Braz. Chem. Soc. 2005, 4, 711-717.

[78]. Sari, N.; Arslan, S.; Logoglu, E.; Sakiyan, I. J. Sci. 2003, 16, 283-288.

[79]. Jayabalakrishnan, C.; Natarajan, K. Trans. Metal Chem. 2002, 27(1), 7579.

[80]. Carcelli, M.; Mazza, P.; Pelizzi, C.; Pelizzi, G.; Zani, F. J. Inorg. Biochem. 1995, 57, 43-62.

[81]. Koch, A. L. J. Clin. Microbiol. Rev. 2003, 16, 673-681. 